\title{
EFFECT OF FEEDINGWATER HYACINTH ON CARCASS TRAITS AND SOME BLOOD COMPONENTS OF RABBITS
}

\author{
T.M.M. Hassan, M.M. Abdella, G.A. El-Sayaad and R.Z.A. Kelyni \\ Department of Animal Production, Faculty of Agriculture, Benha University, Egypt. \\ Corresponding author: tamer.Mohamed@fagr.bu.edu.eg
}

(Received 1/10/2015, Accepted 29/11/2015)

\section{SUMMARY}

$\mathrm{T}$

This experiment was carried out at a private rabbit farm under supervision of Benha University Animal Feed Professors, duration time from May to July 2014 on 48 New Zealand White young male rabbits at 6 weeks of age and 696 grams average live body weight. Rabbits were divided into four groups (each group contains $12 \mathrm{NZW}$ rabbits, with three replicates) for the 8 weeks feeding period to investigate the effect of feeding different levels $(0,25,50$ and $75 \%$ from Egyptian clover) of sun dried water hyacinth on carcass traits and some blood components. The results showed no significant differences between means of live condition scores, carcass weight and dressing percentage due to the feeding groups effect, carcass cuts and offals weight were not significant except for the fur and legs weight $(\mathrm{P}<0.05)$. Chemical analysis of meat showed no significant differences between feeding rabbits groupsexcept for the ash\% $(\mathrm{P}<0.001)$. Blood components of feeding rabbits exhibited significant differences $(\mathrm{P}<0.001)$ for plasma albumin, globulin and total lipids.Present results conclude that, dried water hyacinth leaves and stems may be used as a feed for rabbits to replace $50 \%$ of clover hay in concentrate feed mixture without negative effects on carcass and blood components of growing rabbits.

Keywords: water hyacinth, rabbits, carcass, blood.

\section{INTRODUCTION}

The animal feed stuffs shortage is the most important problem in animal production; therefore, new feed stuffs are required to solve this problem. Water hyacinth (WH) is one of these new feed stuffs, which can replace a part of animal feed to solve this problem. Moreover, animal feed prices are increased yearly,therefore, efforts have been intensified to find more economical feed sources less competitive with human feedstuffs. Using of such non-traditional feeds as WH in animal feeding substantially participates in solving this problem decreases the cost of feeding and hence the marketing price of animal products (Zewil et al., 1993). Rabbit is suitable to raise for meat production due to its high feed conversion efficiency, rabbits use protein more efficiently than broilers and up to $20 \%$ roughages can be included in their diets(Eleraky and Mohamed, 1996). Water hyacinth completely or partially replaced alfalfa without effects on growth rate and reproductive parameters. The optimum inclusion level of WH will depend on the feedstuff substituted in a complete diet. The replacement of Para-grass with WH up to $60 \%$ in rabbit diets improved feed utilization, growth performance and economic returns (Tham, 2015).

The objectives of this study were to investigate the effect of replacing Egyptian clover (Trifolium alexandriunm) hay by sun dried water hyacinth leaves and stems at different levels $(0,25,50$ and $75 \%)$ on carcass traits and some blood components of growing rabbits.

\section{MATERIALS AND METHODS}

\section{Preparation of water hyacinth:}

Water hyacinth (WH) was collected from EL-Qalag, Qalyubia, Egypt. Leaves and stems were separated from the roots of plants and sun dried for 20 days with flipping the plants every three days. 
Dried WH leaves and stems were chopped and used to replace Egyptian clover hay in the concentrate feeding mixture ofa rabbit's diet at different levels $(0,25,50$ and $75 \%)$. Chemical composition of WHand the experimental diets are presented in Table (1).

Table (1). Chemical composition of water hyacinth and the experimental diets.

\begin{tabular}{lcccccc}
\hline \multirow{2}{*}{ Items } & \multicolumn{7}{c}{ Composition on DM basis \% } \\
\cline { 2 - 6 } & DM & CP & EE & NFE & CF & Ash \\
\hline Sun dried water hyacinth & 91.4 & 14.7 & 2.1 & 31.6 & 22.7 & 28.9 \\
T1 CFM*(Control) & 91.1 & 16.1 & 4.3 & 61.0 & 14.2 & 4.4 \\
T2 (25\% water hyacinth) & 91.1 & 16.3 & 4.2 & 60.4 & 14.5 & 4.6 \\
T3 (50\% water hyacinth) & 91.1 & 16.6 & 4.2 & 59.5 & 14.7 & 5.0 \\
T4 (75\% water hyacinth) & 91.0 & 16.4 & 4.1 & 50.1 & 15.1 & 5.3 \\
\hline
\end{tabular}

*CFM (Concentrate feeding mixture) consisted of Hay $30 \%$, Barley $9 \%$, corn Yellow $15 \%$, wheat, bran $30 \%$, soybean meal $14 \%$ and add nitration $2 \%$.

\section{Experimental rabbits and feeding groups:}

Forty eight New Zealand White young male rabbits, 6 weeks of age and about 675 to 717 g live body weight were divided into four groups (each group contains 12 male rabbits and withthree replicates). The first group (control) was fed on the basal diet formulated according to NRC (2004) recommendations. Water hyacinth was used to replace $0,25,50$ and $75 \%$ of Egyptian clover hay in the concentrate feeding mixture diet (control). The feeding period extended for 8 weeks.

All rabbits in each group were individually weighed to the nearest gram at the start of the feeding period and then weekly in the morning before feeding and drinking till the end of the feeding period. Diets were offered twice daily in equal quantities at the 8 am and $4 \mathrm{pm}$ and estimated for each of the four groups every day. Both of consumed diets and refusals (if any) were recorded daily.Ingredients of the experimental diets are presented in Table (2).

Table (2). Feed ingredients of the experimental diets.

\begin{tabular}{lcccc}
\hline Ingredients\% & \multicolumn{3}{c}{ Experimental diets } \\
\cline { 2 - 5 } & T1(Control) & T2 & T3 & T4 \\
\hline Egyptian clover hay & 30 & 22.5 & 15 & 7.5 \\
Water hyacinth & 0 & 7.5 & 15 & 22.5 \\
Yellow corn & 15 & 15 & 15 & 15 \\
Wheat bran & 30 & 30 & 30 & 30 \\
Soybean meal (48\% protein) & 14 & 14 & 14 & 14 \\
Barley & 9 & 9 & 9 & 9 \\
Common salt & 0.5 & 0.5 & 0.5 & 0.5 \\
Limestone & 0.78 & 0.78 & 0.78 & 0.78 \\
Mineral premix & 0.6 & 0.6 & 0.6 & 0.6 \\
Antitoxins and fungi & 0.12 & 0.12 & 0.12 & 0.12 \\
Total & 100 & 100 & 100 & 100 \\
\hline
\end{tabular}

\section{Carcasstraits:}

At the end of the feeding period, 16 male rabbits (four rabbits from each group) were randomly chosen for slaughter test. Rabbits were 14 weeks of age and had nearly similar average live body weight. Live condition scores (LCS) of rabbits (1weak, 2acceptable, 3good, 4very good and 5excellent) were recorded (Armero and Blasco 1992).

Rabbits were slaughtered to determine the performance of carcass characteristics. They were fasted for approximately 16 hours, according to El-Sayaad and Abd EL-Rahman (1990).Rabbits were weighted individually to obtain pre-slaughter weight (fasted weight) and slaughtered by severing the neck with a sharp knife according to Islamic Religion. The slaughter weight was recorded after complete bleeding. 
The head was separated and the body was skinned. Skinning was carried out by removing the skin, including the tail and feet, then after the carcass was opened down and all entrails were removed.Also, lungs, liver, kidneys and heart were weighed.

The weights of the carcass, fur, head and legs were recorded. The carcass for each rabbit was separated into front quarter, chest, loin and hindquarters and their weights were also recorded according to Cheeke (1987). All weights were taken to the nearest gram and related to the fasted weight.

Dressing percentage was calculated using the following equation:

Dressing percentage $=\frac{\text { Dressed weight }(\mathrm{g})}{\text { Fasted weight }(\mathrm{g})} \times 100$

Meat of Longissimus dorsi muscle for each carcass was separated from the bones and weighted, minced, dried, re-weighed, ground and stored at $10 \circ \mathrm{C}$ for chemical analysis according to AOAC (2004).

\section{Blood sampling:}

Individual blood samples were collected at slaughter time from four male rabbits within each group.The blood samples were collected after the addition of EDTA into dry clean tubes. The blood plasma was obtained by centrifuging the blood samples soon after collection at 3000 RPM for 15 minutes.Blood plasma was transferred into vials and stored in a deep freezer at $-20 \circ \mathrm{C}$ for subsequent specific chemical analysis,total protein according to Henry (1964), albumin according to Doumas etal.(1971), total lipids according to Frings etal.(1972). Also, calcium, phosphate and potassium were determined according to American Association for Clinical Chemistry (1977). The concentration of total globulin in each sample was obtained by subtracting albumin concentrates from the total protein concentration and albumin globulin $(\mathrm{A} / \mathrm{G})$ ration was calculated by dividing albumin by total globulin.

\section{Statistical analysis:}

Statistical analysis was carried out by using the least squares procedure for analyzing the data with unequal subclass number as described by SAS (2004).

The statistical model was used as follows:

Where:

$$
Y i j=\mu+T i+e i j
$$

Yijk = the observation of carcass traits, meat chemical analysis and blood plasma component for rabbits; $\mu=$ general mean, common element to all observations;

$\mathrm{Ti}=$ the fixed effect of ith treatment;

eij $=$ random error associated with the individual observation and assumed (NI D) $\square \square \square(0, \square \square 2 \mathrm{e}$ ).

Tests of significance for differences between means were carried out according to Duncan (1955).

\section{RESULTS AND DISCUSSION}

\section{Carcass traits:}

Least square means and standard errors of live condition scores (1-5), carcass weight (g) and dressing percentage are shown in Table (3). Rabbits fed the T1 (control) and T3 diet, recorded the highest LCS (4.25) and carcass weight (1301 g). While, rabbits fed diet containing 50\% water hyacinth (T3) recorded the highest dressing percent $(63.38 \%)$.

The differences between means of live condition scores (1-5), carcass weight (grams) and dressing percentage (\%), due to feeding groups effect, were insignificant (Table 3). These results disagree with those ofZewil et al. (1993) who showed that the dressing percentage was significantly $(\mathrm{P}<0.05)$ depressed when the diet contained 30\% water hyacinth. Eleraky and Mohamed (1996) recorded that dressed weight and dressing percent of NZW rabbits fed on 0,15 and $30 \%$ water hyacinth were $1123.2,1165.4$ and $1094.3 \mathrm{~g} ; 53.7,54.2$ and 52.3\%, respectively, differences between feeding groups were significant 
$(\mathrm{P}<0.05)$. EL-Adawy and Borhami (1999)observed a significant $(\mathrm{P}<0.01$ or $\mathrm{P}<0.05)$ effect of water hyacinth levels in the rabbit's diet on hot carcass weight and dressing percent. El-Adawy et al. (2000) showed that levels of water hyacinth decreased significantly $(\mathrm{P}<0.05$ or $\mathrm{P}<0.01)$ hot carcass weight and dressing percentage, respectively.

Table (3). Least-squares means and standard errors (LSM \pm SE) of rabbits carcass andoffal's weight.

\begin{tabular}{lcccccc}
\hline \multicolumn{1}{c}{ Items } & No. & $\begin{array}{c}\mathrm{T} 1 \\
(\text { Control })\end{array}$ & $\begin{array}{c}\mathrm{T} 2 \\
(25 \% \mathrm{WH})\end{array}$ & $\begin{array}{c}\mathrm{T} 3 \\
(50 \% \mathrm{WH})\end{array}$ & $\begin{array}{c}\mathrm{T} 4 \\
(75 \% \mathrm{WH})\end{array}$ & Sign. \\
\hline $\begin{array}{l}\text { Live condition } \\
\text { score (1-5) }\end{array}$ & 4 & $4.25 \pm 0.47$ & $3.75 \pm 0.47$ & $4.25 \pm 0.47$ & $3.75 \pm 0.47$ & $\mathrm{~ns}$ \\
Carcass weight (g) & 4 & $1301.25 \pm 41.35$ & $1218.75 \pm 41.35$ & $1300.00 \pm 41.35$ & $1170.00 \pm 41.35$ & $\mathrm{~ns}$ \\
Dressing\% & 4 & $61.83 \pm 0.71$ & $62.98 \pm 0.71$ & $63.38 \pm 0.71$ & $63.04 \pm 0.71$ & $\mathrm{~ns}$ \\
Offals weight (grams) & & & & & & \\
Fur & 4 & $317.50 \pm 8.94^{\mathrm{a}}$ & $285.00 \pm 8.94^{\mathrm{bc}}$ & $310.00 \pm 8.94^{\mathrm{ab}}$ & $271.25 \pm 8.94^{\mathrm{c}}$ & $*$ \\
Legs & 4 & $80.00 \pm 4.60^{\mathrm{a}}$ & $72.50 \pm 4.60^{\mathrm{ab}}$ & $62.50 \pm 4.60^{\mathrm{b}}$ & $61.25 \pm 4.60^{\mathrm{b}}$ & $*$ \\
Head & 4 & $132.500 \pm 4.06$ & $125.00 \pm 4.06$ & $130.00 \pm 4.06$ & $123.75 \pm 4.06$ & $\mathrm{~ns}$ \\
Digestive tract & 4 & $341.25 \pm 16.55$ & $315.00 \pm 16.55$ & $321.25 \pm 16.55$ & $292.50 \pm 16.55$ & $\mathrm{~ns}$ \\
Lungs and trachea & 4 & $11.25 \pm 1.69$ & $10.00 \pm 1.69$ & $13.75 \pm 1.69$ & $15.00 \pm 1.69$ & $\mathrm{~ns}$ \\
Liver & 4 & $53.75 \pm 3.64$ & $57.50 \pm 3.64$ & $57.50 \pm 3.64$ & $46.25 \pm 3.64$ & $\mathrm{~ns}$ \\
Kidneys & 4 & $12.50 \pm 1.14$ & $11.25 \pm 1.14$ & $11.25 \pm 1.14$ & $10.00 \pm 1.14$ & $\mathrm{~ns}$ \\
\hline
\end{tabular}

$a, b, c$ Means within any classification, followed by different letters are significantly different $(p<0.05) ; n s=p>0.05$ and $*=p<0.05$

Data of head, legs and body of offal's weight for rabbits fed diets containing different levels of WH are shown in Table (3). The differences due to treatments were not significant except T1 (control) recorded thesignificant $(\mathrm{P}<0.05)$ highest weight of fur and legs whereas $\mathrm{T} 4$ showed the lowest ones (Table 3).

In this respect, EL-Adawy and Borhami (1999) reported that offal's weight percent in growing rabbits fed on 0,50 and $100 \%$ water hyacinth were not significant except liver percent.Moreover,El-Adawy et al. (2000) found that total offal's weight percent of carcass for growing NZW rabbits fed on 0, 18 and $36 \%$ water hyacinth were not significant except of fur and leg. Also, Zewil et al. (1993) indicated that water hyacinth fed to rabbits with levels of 0,10, 20 and 30\% did not affect the relative weight of offal's liver, heart and kidney. Eleraky and Mohamed (1996) stated that experimental diets contain 0, 15 and 30\% water hyacinth did not affect relative weight of liver, heart and kidney.

Rabbits of the T1 (control) recorded the highest weight for hind quarter, loin, chest and front quarter, respectively, being 430.00, 243.75, 227.75 and $185.00 \mathrm{~g}$, respectively (Table 4).However, differences between means of rabbits carcass cuts weight, due to feeding groups effect, were not significant (Table 4).

Table (4). Least-squares means and standard errors $(\mathrm{LSM} \pm \mathrm{SE})$ of factors affecting rabbits carcass cuts weight and meat chemical analysis.

\begin{tabular}{|c|c|c|c|c|c|c|}
\hline Items & No. & $\begin{array}{c}\mathrm{T} 1 \\
(\mathrm{Control})\end{array}$ & $\begin{array}{c}\mathrm{T} 2 \\
(25 \% \mathrm{WH})\end{array}$ & $\begin{array}{c}\mathrm{T} 3 \\
(50 \% \mathrm{WH})\end{array}$ & $\mathrm{T} 4(75 \% \mathrm{WH})$ & Significant \\
\hline \multicolumn{7}{|c|}{ Carcass cuts weight (grams): } \\
\hline Hindquarter & 4 & $430.00 \pm 15.60$ & $420.00 \pm 15.60$ & $418.75 \pm 15.60$ & $368.75 \pm 15.60$ & ns \\
\hline Loin & 4 & $243.75 \pm 15.72$ & $220.00 \pm 15.72$ & $267.50 \pm 15.72$ & $243.75 \pm 15.72$ & ns \\
\hline Chest & 4 & $227.50 \pm 16.20$ & $193.75 \pm 16.20$ & $230.00 \pm 16.20$ & $188.75 \pm 16.20$ & ns \\
\hline Front quarter & 4 & $185.00 \pm 8.54$ & $176.25 \pm 8.54$ & $166.25 \pm 8.54$ & $168.75 \pm 8.54$ & ns \\
\hline \multicolumn{7}{|c|}{ Meat chemical analysis (\%): } \\
\hline Moisture & 4 & $74.87 \pm 0.21$ & $74.64 \pm 0.21$ & $74.48 \pm 0.21$ & $75.01 \pm 0.21$ & ns \\
\hline Protein & 4 & $20.89 \pm 0.19$ & $20.93 \pm 0.19$ & $21.00 \pm 0.19$ & $20.67 \pm 0.19$ & ns \\
\hline Fat & 4 & $1.68 \pm 0.04$ & $1.68 \pm 0.04$ & $1.60 \pm 0.04$ & $1.52 \pm 0.04$ & ns \\
\hline Ash & 4 & $1.37 \pm 0.03 c$ & $1.51 \pm 0.03 b$ & $1.74 \pm 0.03 \mathrm{a}$ & $1.60 \pm 0.03 b$ & $* * *$ \\
\hline
\end{tabular}

$a, b, c$ Means within any classification, followed by different letters are significantly different $(p<0.05) ; n s=p>0.05$ and $* * *=p<0.001$ 
Meat of rabbits of T4 group had the higher moisture percentage $(75.01 \%)$ compared with other treatments being $74.87,74.64$ and $74.48 \%$ for $\mathrm{T} 1$ (control), T2 andT3 group, respectively. Protein percentage was the highest in meat of T3 group (21.00\%) followed by that of T1 (control), T2 and then T4 group $(20.89,20.93$ and $20.67 \%)$ respectively. Otherwise, fat percentage was the highest in T1 (control) and $\mathrm{T} 2$ groups (1.68 \% for both treatments) followed by 1.60 and then $1.52 \%$ for meat of rabbits of T3 and T4 groups, respectively. While, the highest ash percentage (1.74\%) was recorded in T3 group followed by T4, T2 groups and then T1 (control), being (1.60, 1.51 and 1.37\%), respectively, statistical analysis showed differences between treatment for only ash element (Table 4). The present results nearly agree with those reported by El- Adawy et al. (2000) who found that moisture in meat of growing NZW rabbits was 72.83, 73.07 and 72.67\%; $\mathrm{CP}$ was $19.23,19.2$ and $19.18 \%$. But EE was 4.25, 4.13 and $3.97 \%$; ash was $2.48,2.61$ and $2.79 \%$, for rabbits fed 0,18 and $36 \%$ water hyacinth, respectively. They stated that there were no significant differences between means of chemical meat composition, due to rabbits fed on different levels of water hyacinth except for ether extract $(\mathrm{P}<0.05)$.

Generally, the values obtained in the present study are within the range reported by El-Sayaad and Abd-Rahman (1990) and Abdel-Rahim et al. (1994) using different rabbit breeds, ages at slaughter and different diets.

\section{Blood components:}

Means of blood plasma components (total protein, $\mathrm{A} / \mathrm{G}$ ratio, calcium, phosphorus and potassium) for rabbits fed the different levels of water hyacinth were almost similar. However, rabbits of T3 group $50 \%$ WH) achieved the highest values of albumin, globulin and total lipids concentrates $2.4,2.27 \mathrm{~g} / \mathrm{dl}$ and $376.67 \mathrm{mg} / \mathrm{dl}$, respectively, followed by those of the T2 group ( $25 \% \mathrm{WH})$; while the correspond lowest values were recorded for the T1(control) as shown in Table (5). Statistical analysis of the rabbits blood plasma components fed at different levels of water hyacinth was highly significant $(\mathrm{P}<0.001)$ for albumin, globulin and total lipids, but the reverse was true for other rates (Table 7). These results almost agree with those of Eleraky and Mohamed (1996) who found that blood serum components of growing rabbits were $8,8.32$ and $8.18 \mathrm{~g} / \mathrm{dl}$, for total protein; 339.0, 340.0 and $337.0 \mathrm{mg} / \mathrm{dl}$, for total lipids; $3.34,3.61$ and 3.35 $\mathrm{g} / \mathrm{dl}$, for albumin; 4.66, 4.71 and $4.83 \mathrm{~g} / \mathrm{dl}$, for globulin of rabbits fed 0,15 and $30 \%$ water hyacinth, respectively. However,differences betweenrabbits blood component levels due to feeding groups on different levels of water hyacinth $(0,15$ and $30 \%)$ were not significant.

Table (5). Least-squares means and standard errors $(\mathrm{LSM} \pm \mathrm{SE})$ of factors affecting rabbits bloodplasmacomponents.

\begin{tabular}{lcccccc}
\hline Items & No. & $\begin{array}{c}\text { T1 } \\
(\text { Control })\end{array}$ & $\begin{array}{c}\text { T2 } \\
(25 \% \mathrm{WH})\end{array}$ & $\begin{array}{c}\mathrm{T} 3 \\
(50 \% \mathrm{WH})\end{array}$ & $\begin{array}{c}\mathrm{T} 4 \\
(75 \% \mathrm{WH})\end{array}$ & Significant \\
\hline Total protein & 4 & $4.60 \pm 0.09$ & $4.69 \pm 0.09$ & $4.75 \pm 0.09$ & $4.61 \pm 0.09$ & $\mathrm{~ns}$ \\
Albumin & 4 & $2.32 \pm 0.01 \mathrm{~b}$ & $2.37 \pm 0.01 \mathrm{a}$ & $2.40 \pm 0.01 \mathrm{a}$ & $2.33 \pm 0.01 \mathrm{~b}$ & $* * *$ \\
Globulin & 4 & $2.19 \pm 0.007 \mathrm{c}$ & $2.24 \pm 0.007 \mathrm{~b}$ & $2.27 \pm 0.007 \mathrm{a}$ & $2.20 \pm 0.007 \mathrm{c}$ & $* * *$ \\
A/G ratio & 4 & $1.05 \pm 0.005$ & $1.06 \pm 0.005$ & $1.05 \pm 0.005$ & $1.05 \pm 0.005$ & $\mathrm{~ns}$ \\
Total lipids & 4 & $366.45 \pm 0.65 \mathrm{c}$ & $372.18 \pm 0.65 \mathrm{~b}$ & $376.67 \pm 0.65 \mathrm{a}$ & $3.66 .68 \pm 0.65 \mathrm{c}$ & $* * *$ \\
Calcium & 4 & $16.31 \pm 0.16$ & $16.40 \pm 0.16$ & $16.57 \pm 0.16$ & $16.40 \pm 0.16$ & $\mathrm{~ns}$ \\
Phosphor & 4 & $3.81 \pm 0.09$ & $3.76 \pm 0.09$ & $3.87 \pm 0.09$ & $3.85 \pm 0.09$ & $\mathrm{~ns}$ \\
Potassium & 4 & $5.52 \pm 0.09$ & $5.41 \pm 0.09$ & $5.54 \pm 0.09$ & $5.46 \pm 0.09$ & $\mathrm{~ns}$ \\
\hline
\end{tabular}

$a, b, c$ Means within any classification, followed by different letters are significantly different $(p<0.05)$; $n s=p>0.05$ and $* * *=p<0.001$

\section{CONCLUSION}

Present results conclude that, sun dried water hyacinth leaves and stems may be used as a feed for rabbits to replace $50 \%$ of clover hay in concentrate feed mixture without negativeeffects onrabbit's carcass traitsand blood components. 


\section{Hassan et al.}

\section{REFERENCES}

AOAC (2004). Official Methods of Analysis. $15^{\text {th }}$ Association of Official Analytical Chemists, Washington, D.C.

Abdel-Rahim, M.I.; S.A. Tawfeek, Soad and R.S. Amin(1994). Using some of unusual waster vegetable oil as fat supplement in growing rabbits rations. Proceeding of the First International Conference of Rabbit Production in hot Climate, pp. 111-123.

American Association for Clinical Chemistry (1977). Pediatric Clinical Chemistry (S. Meites, Ed) Washington, D. C., P.240.

Armero, E. andA.Blasco (1992). Economic weights for rabbit selection indices. Journal of Applied Rabbit Research, 15:637-642.

Cheeke, P.R. (1987).Rabbit feeding and nutrition. Academic press. Orland. Florida, U.S.A.

Doums, B.T.; W.A. Watson and H.S. Bigges (1971). Albumin standard and measurement of serum albumin with bromocresol green. Clin. Chem. Acta., 31:87-96.

Duncan, D.B. (1955).Multiple ranges and multiple F-test. Biometrics 11:1-42.

El-Adawy, M.M. and B.E. Borhami(1999). Leaf protein concentrate of water hyacinth and berseem in feeding of growing New Zealand White rabbits. Egyptian Journal of Rabbit Science, 9(2):197-214.

El-Adawy, M.M.; B.E. Borhami and A.E.Y. Abdel-Hamid(2000). Utilization of sugar beet pulp and fibrous residues of berseem and water hyacinth in feeding growing New Zealand White rabbits. Egyptian Journal of Rabbit Science; 10(1):1-17.

Eleraky, W.A. and W.E. Mohamed(1996). Growth performance, carcass traits and some related physiological changes of growing rabbits fed on acacia and water hyacinth. Egyptian Journal of Rabbit Science; 6 (1):87-98. 32.

El-Sayaad, G.A.E. and G.A. Abd EL-Rahman(1990). Effect of inclusion of different levels of rumen content in diets for rabbits on carcass traits. Annals Agric. Sci, Moshtohor,28(1):221-234.

Frings, C.S.; T.W. Fendly; R.T. Dunn and C.A. Queen(1972). Improved determination of total serum lipids by the sulfophosphoalanine reaction. Clinical Chemistry, 18: 673-679.

Henry, R.J. (1964). Clinical chemistry . Harper and Publishers, New York.P.181.

NRC (2004). National Research Council: Nutrient requirements of rabbits, (9th Ed.) National Academy Press, Washington, D.C.

SAS (2004). SAS Procedure Guide ”version 9 Ed”. SAS Institute Inc., Cary, NS, USA.

Tham, H.T. (2015). Review article: Utilization of Water Hyacinth as animal feed. Nova Journal of Engineering and Applied Sciences Vol. 4(1):1-6.

Zeweil, H.S.; A.H. Nour and S.A. Abd El-Rahman(1993). Use of water hyacinth (Eichhorniacrassipes martsloms) in rabbit feeding. Egyptian Journal of Rabbit Science; 3(2):191-198. 13. 


\title{
تأثير التغذية بورد النيل على صفات الابيحة وبعض مكونات الام فى الارانب
}

\author{
تامر مسعد محم حسن، حمح تحمل عبداللا، جمال على الدين الصياد و رفعت زعرب عياد قلينى

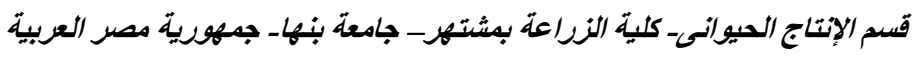

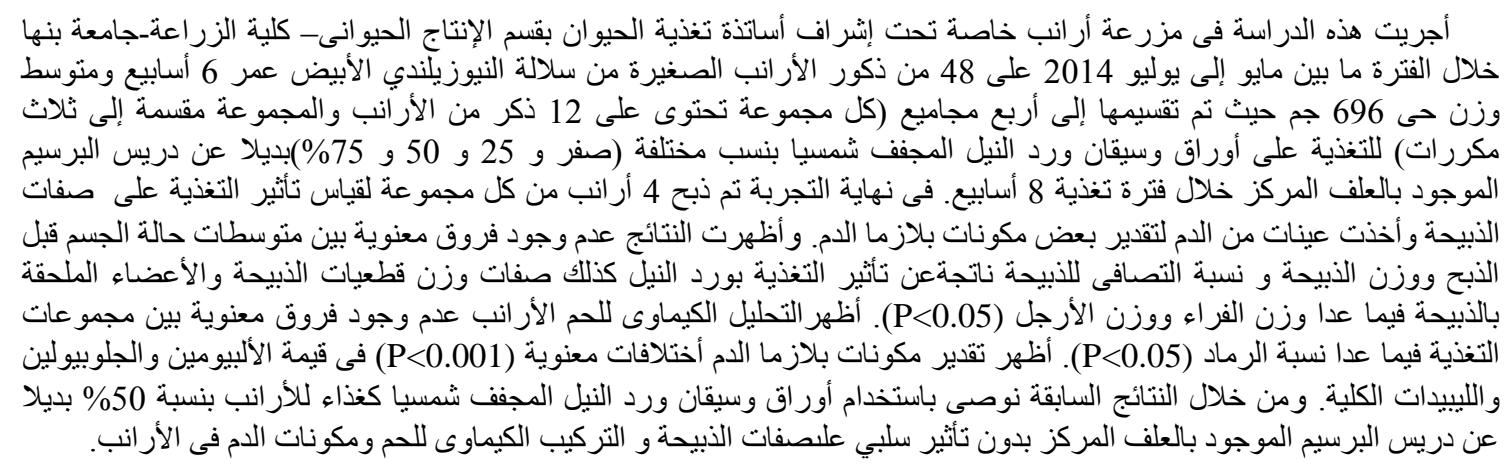

